\title{
Protective Effects of Purple Waxy Corn on Aflatoxin B1- induced Oxidative Stress and Micronucleus in HepG2 Cells
}

\author{
T. SINGTO, W. TASSANEEYAKUL AND S. PORASUPHATANA* \\ Division of Pharmacognosy and Toxicology, Faculty of Pharmaceutical Sciences, Khon Kaen University, Khon Kaen, Thailand
}

\author{
Singto et al.: Suppression of Aflatoxin B1 Toxicity by Purple Corn
}

\begin{abstract}
The purpose of this study was to investigate the protective effects of purple waxy corn extract (Zea may L.) on aflatoxin B1-induced cytotoxicity, oxidative stress and micronuclei in HepG2 cells. Purple waxy corn extract contained phenolics $(187.15-341.65 \mu \mathrm{g}$ gallic acid $/ \mathrm{mg})$, flavonoids $(0.55-21.35 \mu \mathrm{g}$ quercetin/ mg) and anthocyanins (43.70-220.43 mg cyanidin-3-glucoside/l). Antioxidant activities of the extracts were measured using oxygen radical absorbance capacity (1410.70-2214.49 $\mu \mathrm{M}$ trolox/mg) and ferric reducing/ antioxidant power (292.38-612.38 $\mu \mathrm{M}$ trolox/mg) assays. There were significant correlations between phenolic, flavonoid and anthocyanin content and antioxidant activities $(R=0.740-0.778)$ of purple waxy corn extract. Studies in HepG2 cells found that 0.5 and $1 \mathrm{mg} / \mathrm{ml}$ purple waxy corn extract increased cell viability in AFB1-treated HepG2 cells. Purple waxy corn extract reduced intracellular ROS production, increased GSH content and antioxidant enzyme GR, GPx and GST activities and micronucleus in aflatoxin B1-treated HepG2 cells. Therefore, purple waxy corn extract reduced aflatoxin B1 toxicity through induction of antioxidant activities and, thus, inhibited oxidative stress-induced DNA damage caused by aflatoxin B1s.
\end{abstract}

Key words: Mycotoxin, anthocyanins, antioxidant, hepatocellular carcinoma, aflatoxin, purple waxy corn, micronucleus

Aflatoxin $\mathrm{B}_{1}\left(\mathrm{AFB}_{1}\right)$ is a mycotoxin produced by fungi Aspergillus flavus and A. paraciticus and classified as a class I carcinogen due to its association with hepatocellular carcinoma (HCC) in humans ${ }^{[1]}$. $\mathrm{AFB}_{1}$ is widely-found as a contaminate in various crops such as rice, dried fruits, nuts, and sorghum ${ }^{[2]}$, which enables humans to become easily exposed to $\mathrm{AFB}_{1}$ in daily life. The main site for $\mathrm{AFB}_{1}$ metabolism for humans is the liver through cytochrome P450 CYP1A2 and CYP3A4 pathways to form $\mathrm{AFB}_{1}$-8,9-epoxide, a highly reactive metabolite that directly binds to biomolecules, especially DNA and leads to $\mathrm{AFB}_{1}$-DNA adducts. This adduct formation results in gene mutation, and initiation of carcinogenesis. Likewise, $\mathrm{AFB}_{1}$ and $\mathrm{AFB}_{1}-$ 8,9-expoxide also cause the adduct formation via the induction of intracellular reactive oxygen species (ROS) production, which damages biomolecules causing oxidative stress $^{[3-5]}$.

Previous studies reported that $\mathrm{AFB}_{1}$ exposure resulted in oxidative stress. In vitro and in vivo studies showed that $\mathrm{AFB}_{1}$ induced intracellular ROS, lipid peroxidation,

*Address for correspondence

E-mail: psupatra@kku.ac.th

May-June 2020 protein carbonyl and 8-hydroxy-2'-deoxyguanosine (8-OHdG) while decreasing antioxidant enzymatic and non-enzymatic systems ${ }^{[3,6]}$. Therefore, oxidative stress is considered one of the main mechanisms of $\mathrm{AFB}_{1}$ induced toxicity and carcinogenesis.

Recent studies illustrated that various plant extracts expressing antioxidant activity were capable of decreasing $\mathrm{AFB}_{1}$ toxicity and these extracts included, green tea, purple rice, cruciferous vegetables, turmeric and a few others ${ }^{[7-11]}$. Corn is another type of food plant domestically consumed in Southeast Asia. Among those, purple waxy corn (PWC) extract has been reported to contain large quantities of bioactive compounds such as phenolics, flavonoids and anthocyanins and exhibited antioxidant activity as compared to other coloured

This is an open access article distributed under the terms of the Creative Commons Attribution-NonCommercial-ShareAlike 3.0 License, which allows others to remix, tweak, and build upon the work non-commercially, as long as the author is credited and the new creations are licensed under the identical terms 
corns $^{[12]}$. Previous studies also revealed antidiabetic, anticancer, antiinflammatory and especially antioxidant activity of $\mathrm{PWC}^{[13-18]}$. This study was aimed to investigate the effects of $\mathrm{PWC}$ extract on $\mathrm{AFB}_{1}$-induced cytotoxicity, oxidative stress and genotoxicity.

Although the effect of PWC extract on $\mathrm{AFB}_{1}$ detoxification has never been studied, an in vivo study reported the effect of PWC extract on the promotion of antioxidant enzyme activities, such as superoxide dismutase, catalase and glutathione peroxidase $(\mathrm{GPx})^{[14]}$. Accordingly, PWC might reduce cytotoxicity, oxidative stress and genotoxicity induced by $\mathrm{AFB}_{1}$.

\section{MATERIALS AND METHODS}

All chemicals were obtained from Sigma Co. St. Louis (St. Louis, MO, USA). HepG2 cells were obtained from American Type Culture Collection (Manassas, VA, USA). PWC at the maturity phase were obtained from the Vegetable Corn Breeding Project, the Plant Breeding Research Center for Sustainable Agriculture, Khon Kaen University.

\section{Purple corn extraction:}

PWC cobs and seeds were ground in an electrical herb grinder separately, while boiled seed was steamed for 30 min before grinding and then extracted using either deionized water (DI water) or $70 \%$ acetone as solvents with the sample:solvent ration of $25 \mathrm{~g}: 1000 \mathrm{ml}$ under $60^{\circ}$ for $4 \mathrm{~h}$. The extracts were filtered by Whatman no. 1 filter paper to remove solid residual. About $0.1 \% \mathrm{w} / \mathrm{w}$ ascorbic acid was added to protect oxidation before removing water by freezedrying at $-30^{\circ}$ under pressure $130 \mathrm{mbar}$ for $72 \mathrm{~h}$. The dried extracts were preserved at $-20^{\circ[19,20]}$.

\section{Determination of bioactive compounds and antioxidant activity:}

Total phenolic content (TPC) of PWC was evaluated by colorimetric method using Folin-Ciocalteu assay ${ }^{[21]}$. The TPC was calculated as $\mu \mathrm{M}$ gallic acid equivalents relying on a gallic acid standard curve. Total flavonoid content (TFC) of the PWC was determined using aluminium chloride colorimetric method ${ }^{[22]}$. The TFC was calculated as quercetin equivalents ( $\mu \mathrm{g}$ quercetin/ mg extract) following to quercetin standard curve. Total proanthocyanidin content (TAC) was measured by $\mathrm{pH}$-differential method ${ }^{[23]}$ using two different $\mathrm{pH}$ buffer solutions, $\mathrm{pH} 1.00 .025 \mathrm{M} \mathrm{KCl}$ and $\mathrm{pH} 4.50 .4$ $\mathrm{M}$ sodium acetate. The extracts were mixed with these two buffers and measured absorbance at both 510 and
$700 \mathrm{~nm}$ for calculating TAC as $\mathrm{mg}$ cyanidin-3glucoside/g extract.

Antioxidant activity using oxygen radical absorbance capacity (ORAC) assay was based on hydrogen atom transfer reactions. The ORAC was calculated from area under the curve as trolox equivalents $(\mu \mathrm{M}$ trolox $/ \mathrm{mg}$ plant extract $)^{[24]}$. Antioxidant activity also determined by ferric reducing/antioxidant power (FRAP) assay. The antioxidant activity evaluated by FRAP was calculated as trolox equivalent ( $\mu \mathrm{M}$ trolox/mg plant extract $)^{[19,25]}$.

\section{Cell cytotoxicity:}

The effect of PWC extract on cell viability of HepG2 cells for determining non-toxic concentration was measured using sulforhodamine B colorimetric assay (SRB assay $)^{[26]}$. HepG2 cells (25 000 cells/well) were seeded in to 96 -well plate and incubated at $37^{\circ}$ and $5 \% \mathrm{CO}_{2}$ for $24 \mathrm{~h}$. The combinations of non-toxic concentration of extracts $(0.01-1 \mathrm{mg} / \mathrm{ml})$ and $6 \mu \mathrm{g} / \mathrm{ml}$ $\mathrm{AFB}_{1}$ were also treated and incubated for $24 \mathrm{~h}$. Cell viability was compared with $0.12 \%$ DMSO group as $\%$ viability of control.

\section{Intracellular ROS production:}

Intracellular ROS production in HepG2 cells was measured using dichlorofluorescein (DCF) assay ${ }^{[27]}$. Cells $\left(4 \times 10^{4}\right.$ cells/well) were seeded into black 96-well plate and incubated at $37^{\circ}$ and $5 \% \mathrm{CO}_{2}$ for $48 \mathrm{~h}$. Then, cells were washed twice with PBS before incubating with $50 \mu \mathrm{M}$ DCFH-DA diluted in PBS for $45 \mathrm{~min}$. The fluorescence intensity as relative fluorescence units was read at 485 (excitation) and 528 (emission) nm, respectively. Percent intracellular ROS production of control was calculated and compared to $0.12 \%$ DMSO group.

\section{Determination of glutathione content and antioxidant enzyme activities:}

Cells $(5 \times 105$ cells/well) were seeded into 6-well plate and incubated at $37^{\circ}$ and $5 \% \mathrm{CO} 2$ for $24 \mathrm{~h}$. Then, the cells were treated with substances and then incubated for $24 \mathrm{~h}$. They were harvested by $0.05 \%$ trypsin-EDTA. PBS was added into cell pellet. Then, it was sonicated for $60 \mathrm{~s}$ twice. The solution was centrifuged at $4^{\circ}$, $9000 \mathrm{rpm}$ for $10 \mathrm{~min}$ and supernatant was kept at $-80^{\circ}$ to examine enzyme activities and glutathione content. Protein content was measured by Bradford assay ${ }^{[28]}$. Regarding GSH content, the reaction was measured change of DTNB into 5-thio-2-nitrobenzoic acid $(\mathrm{TNB})^{[29]}$. GPx activity was determined by measuring 
the reduction in NADPH concentration ${ }^{[30]}$. Glutathione reductase (GR) activity was determined by measuring the decrease of NADPH concentration resulted from GR-catalysed GSSG to GSH ${ }^{[31]}$. GST activity in the cell lysate was also determined using Sigma GST assay kit.

\section{Micronucleus:}

HepG2 cells were seeded into $100 \mathrm{~mm}$ dishes $(6 \times 106$ cells $)$ and incubated at $37^{\circ}$ and $5 \% \mathrm{CO} 2$ for $24 \mathrm{~h}$. Each dish was treated with test compounds for $24 \mathrm{~h}$. Then, the cells were incubated with $4 \mu \mathrm{g} / \mathrm{ml}$ CytB for $48 \mathrm{~h}$. Cells were harvested by $0.05 \%$ trypsin-EDTA and centrifuged at $1500 \mathrm{rpm}$ for $10 \mathrm{~min}$ and the cell pellet was resuspended in $5.6 \mathrm{mg} / \mathrm{ml} \mathrm{KCl}$ hypotonic solution and centrifuged at $1500 \mathrm{rpm}$ for $10 \mathrm{~min}$. Samples were fixed by dropping $10 \mathrm{ml}$ fixative solution (3:1 methanol:acetic acid) followed by spinning at $1500 \mathrm{rpm}$ for $10 \mathrm{~min}$. Cell slide was dried and stained with $10 \%$ Giemsa stain for 15 min. Number of micronuclei was counted under an inverted light microscope at $300 \mathrm{X}$. The frequency of micronuclei in 300 binucleated cells was evaluated $(n=3)^{[32]}$.

\section{Statistical analysis:}

Data was analysed by SPSS version 19 by multiple comparison Dunnett's test for parametric data and Kruskal-Walis for non-parametric data. The correlation test used the Pearson's correlation coefficient. The $50 \%$ effective concentration $\left(\mathrm{EC}_{50}\right)$ was calculated using the GraphPad software.

\section{RESULTS AND DISCUSSION}

The contents of bioactive components TPC, TFX and TAC of the PWC extracts are shown in Table 1. The TPC content of PWC extracts was $161.65 \pm 1.80$ $217.07 \pm 2.29 \mu \mathrm{g}$ gallic acid $/ \mathrm{mg}$. When compared to each solvent group, both cob and boiled seed DI water extract contained higher phenolic content than the $70 \%$ acetone extract.
The PWC extracts contained TFC at $0.17 \pm 0.10$ $13.76 \pm 0.41 \mu \mathrm{g}$ quercetin $/ \mathrm{mg}$ while TAC determined by the pH-differential method was $19.20 \pm 2.18$ $142.94 \pm 4.88 \mathrm{mg} \mathrm{C} 3 \mathrm{G} / \mathrm{mg}$. The DI water and $70 \%$ acetone extracts of corn cob contained TFC content was greater than that of any of the other extracts. TAC of corn cob extracts was also dramatically higher than seed and boiled seed extracts (Table 1).

Antioxidant activity was evaluated using assays based on hydrogen atom transfer reactions (ORAC assay) and electron transfer (FRAP assay). The results of antioxidant activity were displayed in Table 1 . The PWC extracts exhibited antioxidant activity in the range of $1241.75 \pm 0.83-2138.51 \pm 138.65 \mu \mathrm{M}$ trolox $/ \mathrm{mg}$ extract as determined by the ORAC assay. Corn cob DI water extract had the highest antioxidant activity. In the FRAP assay, PWC extracts exhibited antioxidant activity in the range of $9.21 \pm 28.21-477.14 \pm 26.30 \mu \mathrm{M}$ trolox/mg. The antioxidant activity of PWC DI water extract was higher than that of the $70 \%$ acetone extract. Of particular note was that the boiled seed extract contained the highest activity (Table 1).

There were correlations between bioactive compounds and antioxidant activity of the PWC extracts $(\mathrm{p}<0.05)$. TFC and TAC were moderately correlated to antioxidant activity determined by ORAC with a correlation coefficient of 0.75 and 0.78 , respectively, while TPC moderately correlated to antioxidant activity measured by FRAP assay with $\mathrm{R}=0.74$.

Regarding the content of bioactive compounds and antioxidant activity, corn cob DI water extract was selected for screening on $\mathrm{AFB}_{1}$-induced toxicity in HepG2 cells due to the high content of bioactive compounds and antioxidant activity in the extract. Concentration sin the range of $0.1-3 \mathrm{mg} / \mathrm{ml}$ of extract was applied to HepG2 cells for $24 \mathrm{~h}$. Fig. 1A showed the effect of PWC cob extract at different concentrations on $\%$ cell viability and the results showed that cell viability was significantly increased after treatment with

TABLE 1: BIOACTIVE COMPOUNDS AND ANTIOXIDANT ACTIVITY OF THE PWC EXTRACTS

\begin{tabular}{lcccccc}
\hline \multirow{2}{*}{ Solvent } & \multirow{2}{*}{ Part of PWC } & \multicolumn{3}{c}{ Bioactive compound } & \multicolumn{2}{c}{ Antioxidant activity } \\
\cline { 3 - 7 } & & TPC & TFC & TAC & ORAC & FRAP \\
\hline \multirow{2}{*}{$70 \%$} & Cob & $133.09 \pm 8.63$ & $13.76 \pm 0.41$ & $113.55 \pm 2.19$ & $1796.78 \pm 61.64$ & $9.21 \pm 28.21$ \\
acetone & Seed & $203.87 \pm 9.85$ & $4.29 \pm 0.64$ & $23.29 \pm 1.14$ & $1496.33 \pm 11.88$ & $52.86 \pm 28.49$ \\
& Boiled seed & $161.65 \pm 1.80$ & $3.81 \pm 0.42$ & $21.64 \pm 0.33$ & $1241.75 \pm 0.83$ & $61.19 \pm 28.31$ \\
\multirow{3}{*}{ DI water } & Cob & $187.15 \pm 2.46$ & $8.11 \pm 0.14$ & $142.94 \pm 4.88$ & $2138.51 \pm 138.65$ & $266.67 \pm 24.06$ \\
& Seed & $177.27 \pm 2.78$ & $0.17 \pm 0.10$ & $19.20 \pm 2.18$ & $1299.77 \pm 49.36$ & $370.48 \pm 26.79$ \\
& Boiled seed & $217.07 \pm 2.29$ & $0.55 \pm 0.09$ & $43.70 \pm 2.61$ & $1410.70 \pm 13.23$ & $477.14 \pm 26.30$ \\
\hline
\end{tabular}

TPC ( $\mu$ g gallic acid/mg extract); TFC ( $\mu$ g quercetin/mg extract) TAC ( $\mu$ g cyaniding-3-glucoside /mg extract) and antioxidant activity determined by ORAC and FRAP ( $\mu$ M Trolox/mg extract); mean \pm SD 
$0.1-1 \mathrm{mg} / \mathrm{ml}$ PWC cob extract with \% viability values of $121.17 \pm 7.41,147.38 \pm 15.94,123.55 \pm 11.04$ and $121.17 \pm 10.22$, respectively $(\mathrm{p}<0.05)$. On the contrary, high concentrations of 2 and $3 \mathrm{mg} / \mathrm{ml} \mathrm{PWC} \mathrm{cob} \mathrm{extract}$ resulted in significantly reduced the $\%$ cell viability to $91.43 \pm 6.48$ and $60.64 \pm 7.76 \%$, respectively $(\mathrm{p}<0.05)$.

PWC cob extract in a range of $0.1-1 \mathrm{mg} / \mathrm{ml}$ was cotreated with $6 \mu \mathrm{g} / \mathrm{ml} \mathrm{AFB}_{1}$ in HepG2 cells for $24 \mathrm{~h}$. Percent cell viability of control was calculated and compared to the control group ( $0.12 \% \mathrm{DMSO})$. The cotreatment of $\mathrm{AFB}_{1}$ and 0.5 and $1 \mathrm{mg} / \mathrm{ml} \mathrm{PWC} \mathrm{cob} \mathrm{extract}$ had a \% cell viability of $87.90 \pm 4.07$ and $89.25 \pm 2.01$, respectively $(\mathrm{p}<0.05)$, higher than treatment with

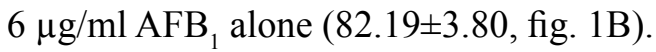

The intracellular ROS production was measured after co-exposure of $3 \mu \mathrm{g} / \mathrm{ml} \mathrm{AFB}_{1}$ and cob extract in a range from 0.1 to $1 \mathrm{mg} / \mathrm{ml}$ for $24 \mathrm{~h}$ using DCF assay. The results showed that $3 \mu \mathrm{g} / \mathrm{ml}$ significantly increased intracellular ROS production compared to the corresponding control $(p<0.05)$ (fig. 2). It was also found that co-treatment with $\mathrm{AFB}_{1}$ and cob in the concentrations of 0.1 and $1 \mathrm{mg} / \mathrm{ml}$ reduced intracellular ROS compared to treatment with $\mathrm{AFB}_{1}$ alone in a dosedependent manner with EC50 as $0.356 \mathrm{mg} / \mathrm{ml}$.

The study of the effect of PWC cob extract on GSH content demonstrated that $3 \mu \mathrm{g} / \mathrm{ml} \mathrm{AFB}_{1}$ resulted in $74.48 \pm 5.36 \%$ of GSH content, a significant GSH content reduction from that of the control group. Moreover, the co-treatment of $3 \mu \mathrm{g} / \mathrm{ml} \mathrm{AFB}_{1}$ with $1 \mathrm{mg} / \mathrm{ml}$ PWC cob extract resulted in $107.46 \pm 6.86 \%$ of the GSH content that the control group contained, a significant GSH content increase when compared to treatment with $\mathrm{AFB}_{1}$ alone (fig. 3A).

With respect to GPx activity, the results indicated that $3 \mu \mathrm{g} / \mathrm{ml}$ AFB1 reduced GPx activity compared to that of

A

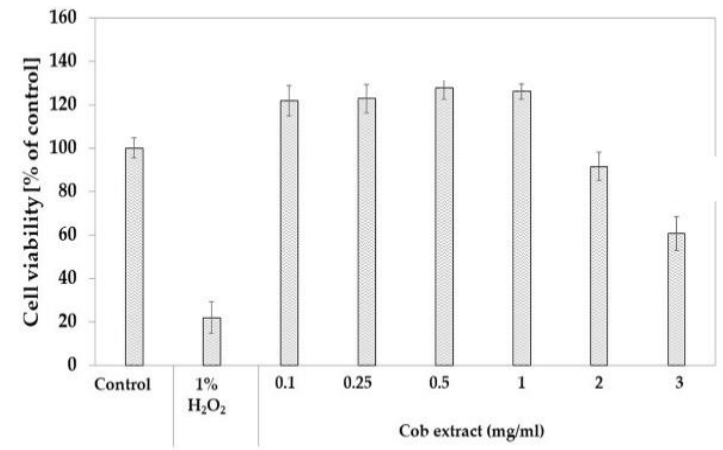

the control group ( $\%$ of control as $82.24 \pm 6.84, \mathrm{p}<0.05$ ). It was also found that co-treatment with $3 \mu \mathrm{g} / \mathrm{ml} \mathrm{AFB}_{1}$ and cob extract in the concentrations of 0.1 and $1 \mathrm{mg} /$ $\mathrm{ml}$ significantly induced GPx activity, higher than with $\mathrm{AFB}_{1}$ treatment alone. The $\%$ of control levels were $92.09 \pm 3.43(\mathrm{p}<0.05)$ and $96.12 \pm 3.71$ for co-treatment with 0.1 and $1 \mathrm{mg} / \mathrm{ml} \mathrm{cob}$ extract, respectively (fig. 3B).

The effect of cob extract on GR activity found that co-treatment with $3 \mu \mathrm{g} / \mathrm{ml} \mathrm{AFB}_{1}$ and $1 \mathrm{mg} / \mathrm{ml} \mathrm{cob}$ significantly increased GR activity as \% of control compared to treatment with $3 \mu \mathrm{g} / \mathrm{ml} \mathrm{AFB}_{1}$ alone. Furthermore, the activity of co-treatment with $1 \mathrm{mg} / \mathrm{ml}$ cob did not significantly differ from that of the control group ( $>0.05$ ). About .01 and $0.1 \mathrm{mg} / \mathrm{ml} \mathrm{cob}$ extract did not increase activity (fig. 3C).

With respect to glutathione-S-transferase (GST) activity, the results revealed that $3 \mu \mathrm{g} / \mathrm{ml} \mathrm{AFB}_{1}$ significantly reduced GST activity when compared to the control group $(\mathrm{p}<0.05)$ with the $\%$ GST activity at $87.90 \pm 1.53$. The results also showed that co-treatment with $3 \mu \mathrm{g} / \mathrm{ml} \mathrm{AFB}_{1}$ and 0.01 and $0.1 \mathrm{mg} / \mathrm{ml} \mathrm{cob}$ extract had \% GST activity of $94.12 \pm 4.95 \%$ and 93.10 $\pm 3.10 \%$, respectively, higher than treatment with $\mathrm{AFB}_{1}$ alone ( $\mathrm{p}<0.05$, fig. 3D).

After treatment with $3 \mu \mathrm{g} / \mathrm{ml} \quad \mathrm{AFB}_{1}$, the number of micronucleated cells in 300 binucleated cells significantly increased 1.8-fold compared to the corresponding control $(\mathrm{p}<0.05)$. Co-treatment with $3 \mu \mathrm{g} / \mathrm{ml} \mathrm{AFB}_{1}$ and $0.01 \mathrm{mg} / \mathrm{ml}$ PWC cob extract resulted in no micronucleus reduction whereas $1 \mathrm{mg} / \mathrm{ml}$ PWC cob extract resulted in a micronucleus decrease compared to treatment with $\mathrm{AFB}_{1}$ alone $(\mathrm{p}<0.05)$.

Oxidative stress is the main mechanism of AFB1induced toxicity because the production of free radicals is induced during $\mathrm{AFB}_{1}$ metabolism by CYP450 and $\mathrm{AFB}_{1}-8,9$-expoxide as well. These free radicals could B

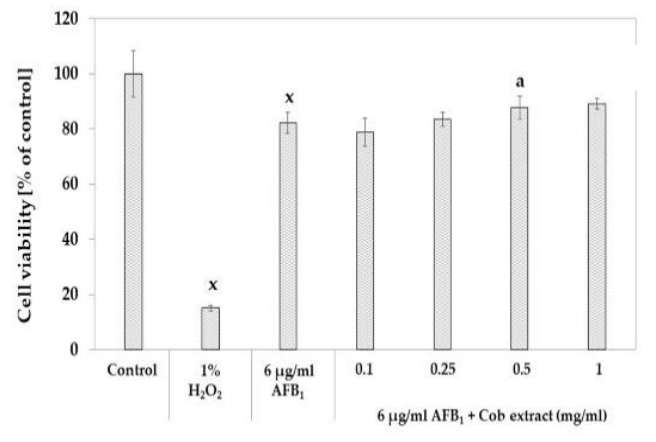

Fig. 1: Viability of HepG2 cells treated with PWC cob extracts alone or co-treated AFB Cell viability as \% of control) of HepG2 cells treated with A. PWC cob extract $0.1-3 \mathrm{mg} / \mathrm{ml}$ and B. co-treated with $6 \mu \mathrm{g} / \mathrm{ml} \mathrm{AFB} \mathrm{B}_{1}$ for $24 \mathrm{~h}$ at $5 \% \mathrm{CO} 2$ and $37^{\circ}$. Mean $\pm \mathrm{SD}, \mathrm{n}=5$; $\mathrm{x}$ indicated difference from control group with $\mathrm{p}<0.05$, and a indicated difference from AFB1 group with $\mathbf{p}<\mathbf{0 . 0 5}$ 
damage lipids, proteins, carbohydrates and DNA and, thus, contribute to cell injury and DNA damage, leading to liver carcinogenesis ${ }^{[3,5]}$. Numerous studies confirmed that phenolics-rich plants were capable of reducing $\mathrm{AFB}_{1}$-induced toxicities. To illustrate, ginger extract enhanced antioxidant enzyme activities and reduced hepatotoxicity induced by $\mathrm{AFB}_{1}$ in an in vivo study ${ }^{[33]}$. In addition, there are studies displayed that anthocyanin and anthocyanin-rich plants showed the ability to reduce $\mathrm{AFB}_{1}$ toxicities via alleviation of phase $\mathrm{I}$ and II metabolism, chromosome aberration, biomolecule

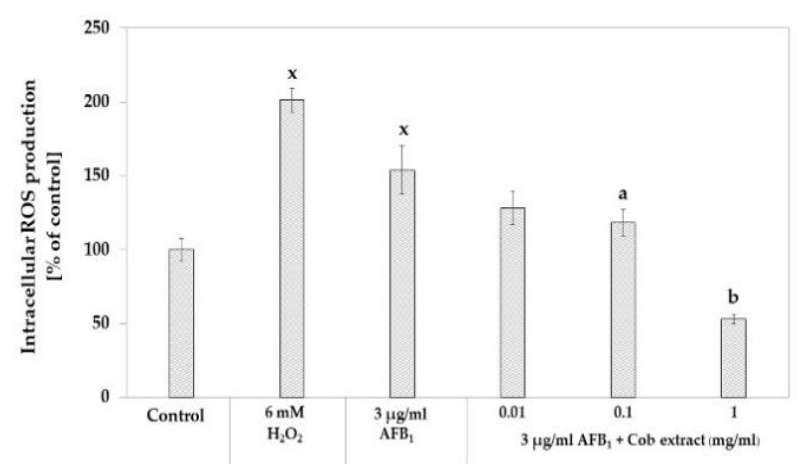

Fig. 2: ROS production in HepG2 cells co-treated with $\mathrm{AFB}_{1}$ and PWC cob extract

The intracellular ROS production as \% of control) in HepG2 cells co-treated with $3 \mu \mathrm{g} / \mathrm{ml} \mathrm{AFB}_{1} 0.01$ to $1 \mathrm{mg} / \mathrm{ml}$ of PWC cob extract for $24 \mathrm{~h}$ at $5 \% \mathrm{CO} 2$ and $37^{\circ}$, mean $\pm \mathrm{SD}, \mathrm{n}=5$

A

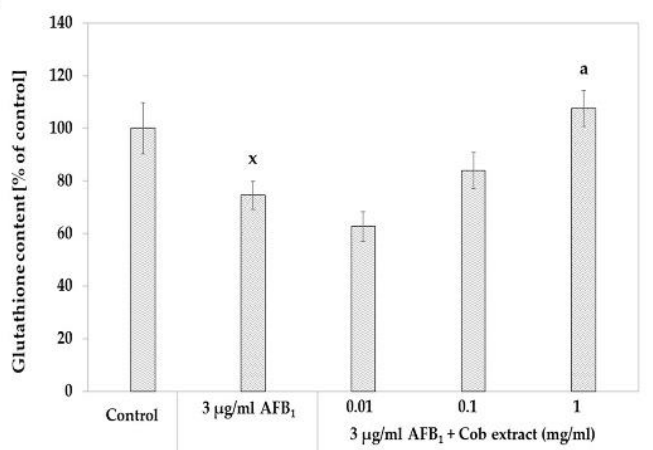

C

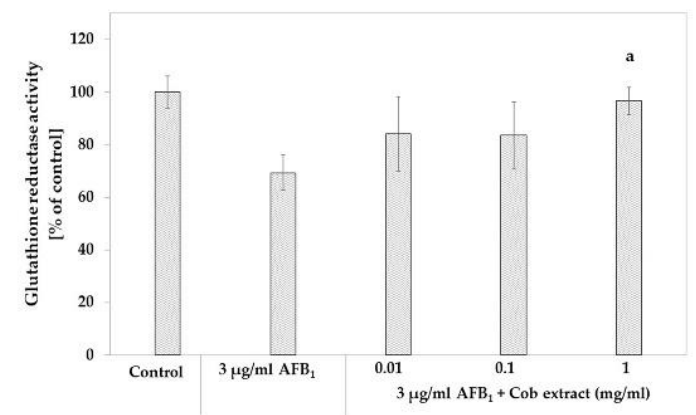

synthesis, DNA fragmentation and oxidative stress in in vivo studies ${ }^{[10,34]}$. Regarding flavonoids, flavonoid fraction of Rhus verniciflua extract increased the activity of ROS-detoxifying enzymes ${ }^{[35]}$. Consequently, phenolics, flavonoid and anthocyanin assured to reduce $\mathrm{AFB}_{1}$ toxicity and antioxidant properties clearly showed protective effects of $\mathrm{AFB}_{1}$-induced toxicity.

This study was aimed at investigating whether PWC extract was able to protect $\mathrm{AFB}_{1}$-induced cytotoxicity, oxidative stress and micronucleus in HepG2 cells. After three parts (cob, seed and boiled seed) of PWC were extracted with DI water and $70 \%$ acetone, the contents of bioactive components such as phenolics, flavonoids and anthocyanins were determined. The TPC was 133.09-217.07 $\mu \mathrm{g}$ gallic acid $/ \mathrm{mg}$, flavonoid content was $0.17-13.76 \mu \mathrm{g}$ quercetin $/ \mathrm{mg}$ and anthocyanin content was 19.20-142.94 mg cyanidin-3-glucoside/l in these PWC extracts. The antioxidant activities were measured by ORAC $(1241.75-2138.51 \mu \mathrm{M}$ trolox $/ \mathrm{mg})$ and FRAP (9.21-477.14 $\mu \mathrm{M}$ trolox/mg). Bioactive compounds TPC, TFC and TAC and antioxidant activity seemed to depend on part of PWC and types of solvent. From these investigations, PWC cob DI water extract was selected for studying the effects on $\mathrm{AFB}_{1}$-induced toxicity in HepG2 cells due to their optimized content of bioactive compounds and antioxidant activity.

B

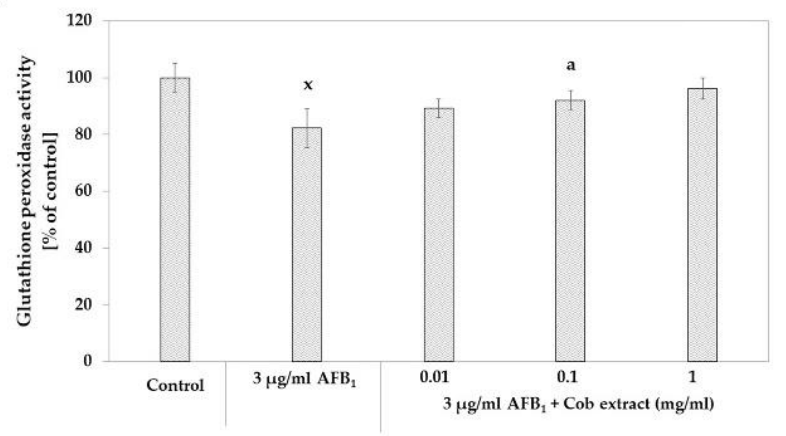

D

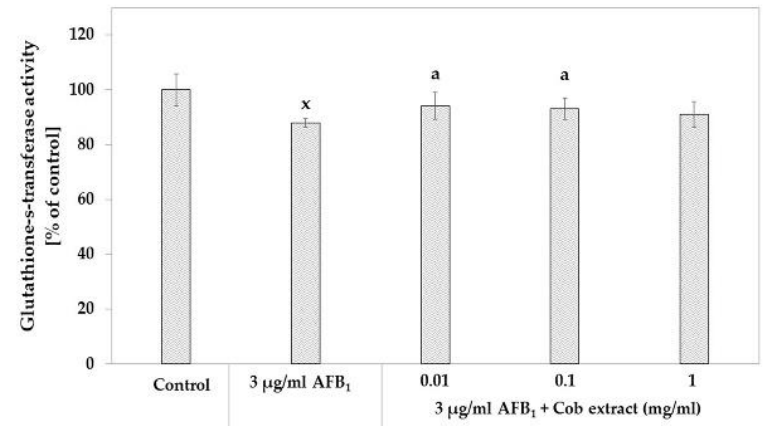

Fig. 3: Effect of AFB and PWC cob extracts of GSH, GPx, GR and GST in HepG2 cells A. GSH content as \% of control in HepG2 cells co-treated with $6 \mu \mathrm{g} / \mathrm{ml} \mathrm{AFB}$ and $0.1-1 \mathrm{mg} / \mathrm{ml} \mathrm{of} \mathrm{PWC} \mathrm{cob} \mathrm{for} 24 \mathrm{~h}$, B. GPx activity as \% of control, $C$. GR activity as $\%$ of control and D. GST activity as \% of control, mean \pm SD, $n=5$ 
Furthermore, there were correlations between bioactive compounds and antioxidant activity of PWC. TPC moderately correlated to antioxidant activity as measured by the FRAP assay with $\mathrm{R}=0.74(\mathrm{p}<0.05)$. It could be observed from seed and boiled seed DI water and $70 \%$ acetone extracts had high TPC and high antioxidant activity whereas cob extracts contained low TFC and low antioxidant activity. In addition, TFC and TAC moderately correlated to antioxidant activity determined by ORAC with $\mathrm{R}=0.75$ and 0.78 , respectively. PWC Cob extracts had the highest TFC and TAC compared to the other extracts. It also had higher antioxidant activity than any other parts of PWC (Table 1). Accordingly, the antioxidant activity of PWC depended on the contents of these bioactive compounds.

HepG2 cells were used as a model in this study. These were widely accepted as a model for drug metabolizing and liver toxicity studies. Despite some limitations (ex., low activities of phase I and II metabolizing enzymes), their activities are rather stable, not relying on passage ${ }^{[36]}$. Hence, HepG2 cells were commonly used for studying $\mathrm{AFB}_{1}$-induced hepatotoxicity (ex., studying the effects of zinc on liver toxicity and DNA damage induced by $\mathrm{AFB}_{1}$ and studying the effects of carotenoids inhibiting molecular toxicity in $\mathrm{AFB}_{1}$ induced HepG2 cells ${ }^{[37,38]}$. To evaluate the cytotoxicity of cob extract for choosing a non-toxic concentration, HepG2 cells were incubated with cob extract for $24 \mathrm{~h}$ and then measured using SRB assay. The results found that $0.1-1 \mathrm{mg} / \mathrm{ml}$ cob extract not only non-toxic but also increased viability of HepG2 cells.

Regarding the effect of cob extract on $\mathrm{AFB}_{1}$-induced cytotoxicity, the results revealed that 0.5 and $1 \mathrm{mg} / \mathrm{ml}$ cob extract slightly increased the \% viability in $\mathrm{AFB}_{1}$ treated HepG2 cells $(\mathrm{p}<0.05)$. The small influence on cell viability was also reported in prior studies; zinc and Allium fistulosum extract minimally increased viability of $\mathrm{AFB}_{1}$-treated HepG2 cells ${ }^{[37,39]}$. Important as well is that this protection effect was also found in other extracts containing phenolics, flavonoids and anthocyanins $^{[33,38]}$.

For antioxidant studies, intracellular ROS production, GSH content, GPx, GR and GST activities, the reliable markers for oxidative stress, were examined. The results indicated that after incubation with $3 \mu \mathrm{g} / \mathrm{ml} \mathrm{AFB}_{1}$ for $24 \mathrm{~h}$, intracellular ROS production was induced while GSH content, GPx, GR and GST activities were reduced compared to the control group. These findings confirmed that $\mathrm{AFB}_{1}$ could cause oxidative stress in HepG2 cells (fig. 2, 3 and 4). The effects of $\mathrm{AFB}_{1}$ on decreasing the GSH content and induction of ROS corroborate the findings of several previous studies performed under similar conditions, $3 \mu \mathrm{g} / \mathrm{ml} \mathrm{AFB}_{1}$ and incubated for $24 \mathrm{~h}^{[33,34,37,39]}$.

The most interesting finding is that the PWC cob extract could reduce ROS production induced by $\mathrm{AFB}_{1}$ in a dose-dependent manner, especially $1 \mathrm{mg} / \mathrm{ml}$ cob extract was more effective in reducing ROS by more than $50 \%$ of that produced by $\mathrm{AFB}_{1}$ group. In addition, PWC cob extract could also increase glutathione content and GPx activity in a dose-dependent manner while only 0.01 and $0.1 \mathrm{mg} / \mathrm{ml}$ PWC cob extract were capable of increasing GST activity as a function of cellular detoxification against xenobiotics and against oxidative stress. In addition, $1 \mathrm{mg} / \mathrm{ml}$ cob extract was able to activate GR activity. These results agreed with those of a previous study in which in vivo antioxidant activity played a critical role in ameliorating diseases, such as diabetes, Opisthorchis viverrini infection and diabetic cataract ${ }^{[14,40,41]}$.

Apart from $\mathrm{AFB}_{1}$-induced genotoxicity, prior studies reported that $\mathrm{AFB}_{1}$-induced micronucleus and chromosome aberration. This study also found that $\mathrm{AFB}_{1}$ caused micronuclei formation. Co-treatment with $0.01 \mathrm{mg} / \mathrm{ml} \mathrm{cob}$ extract did not reduce the frequency of micronucleated cells; however, $1 \mathrm{mg} / \mathrm{ml}$ cob extract reduced the frequency of micronucleated cells.

In conclusion, co-treatment of $3 \mu \mathrm{g} / \mathrm{ml} \mathrm{AFB1}$ with $0.01-1 \mathrm{mg} / \mathrm{ml}$ of PWC cob extracts clearly showed antioxidative stress induced by $\mathrm{AFB}_{1}$ through reduction of ROS production and induction of GSH content, GR and GPx as well as GST activities. Furthermore, PWC extract also lowered micronucleus count and cytotoxicity. Both induction of oxidative stress and genotoxicity are the main mechanisms leading to HCC, therefore, PWC extracts could contain anticancer

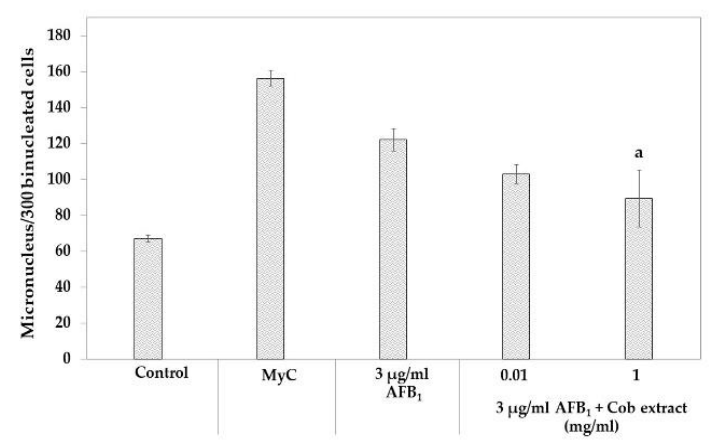

Fig. 4: Effect of co-treatment of $\mathrm{AFB}_{1}$ and PWC cob extract micronucleated cells

Effect of co-treatment with $3 \mu \mathrm{g} / \mathrm{ml} \mathrm{AFB}_{1}$ and cob extract on the number of micronucleated cells in 300 binucleated cells with $\mathbf{n}=\mathbf{3}$ 
substances, the molecular mechanism of which needs to be explored further.

\section{Acknowledgments:}

We thank the Vegetable Corn Breeding Project, the Plant Breeding Research Center for Sustainable Agriculture, Khon Kaen University for providing cob sample of PWC. We greatly acknowledge the financial support provided by Development and Promotion of Science and Technology Talent Project (DPST) organized by Ministry of Science and Technology, Thailand; the National Research Council of Thailand (NRCT); and Faculty of Pharmaceutical Sciences, Khon Kaen University, Khon Kaen Thailand.

\section{REFERENCES}

1. IARC. Aflatoxin. In: IARC Monogr Eval Carcinog Risks Hum. Lyon: IARC Press; 2002. p. 225-48.

2. Rushing BR, Selim MI. Aflatoxin B1: A Review on Metabolism, Toxicity, Occurrence in Food, Occupational Exposure, and Detoxification Methods. Food Chem Toxicol 2019;124:1-100.

3. Bbosa GS, Kitya D, Odda J, Ogwal-Okeng J. Aflatoxins Metabolism. Health (Health (Irvine Calif)) 2013;5:14-34.

4. Bedard LL, Massey TE. Aflatoxin B1-Induced DNA Damage and Its Repair. Cancer Lett 2006;241:174-83.

5. Yilmaz S, Kaya E, Kisacam M. The Effect on Oxidative Stress of Aflatoxin and Protective Effect of Lycopene on Aflatoxin Damage. In: Lukman A, editor. Aflatoxin - Control, Analysis, Detection and Health Risks. London: IntechOpen; 2017. p. 6790.

6. Tulayakul P, Dong KS, Li JY, Manabe N, Kumagai S. The Effect of Feeding Piglets with The Diet Containing Green Tea Extracts or Coumarin on In Vitro Metabolism of Aflatoxin B1 By Their Tissues. Toxicon 2007;50:339-48.

7. Luo H, Tang L, Tang M, Billam M, Huang T, Yu J, et al. Phase IIa Chemoprevention Trial of Green Tea Polyphenols in High-Risk Individuals of Liver Cancer: Modulation of Urinary Excretion of Green Tea Polyphenols and 8-Hydroxydeoxyguanosine. Carcinogenesis 2005;27:262-8.

8. Ito Y. Suppressive Effect of (-)-Epigallocatechin Gallate on 7,12 Dimethylbenz[a]anthracene-Induced Chromosome Aberrations in Rat Bone Marrow Cells. Environ Mutagen Res 2006;27:177-84.

9. Ito Y, Ohnishi S, Fujie K. Chromosome Aberrations Induced by Aflatoxin B1 in Rat Bone Marrow Cells In Vivo and Their Suppression by Green Tea. Mutat Res 1989;222:253-61.

10. Suwannakul N, Punvittayagul C, Jarukamjorn K, Wongpoomchai R. Purple Rice Bran Extract Attenuates the Aflatoxin B1-Induced Initiation Stage of Hepatocarcinogenesis by Alteration of Xenobiotic Metabolizing Enzymes. Asian Pac J Cancer Prevent 2016;16:3371-6.

11. Fiala LJ, Egner AP, Wiriyachan N, Ruchirawat M, Kensler HK, Gerald N, et al. Sulforaphane-Mediated Reduction of Aflatoxin B1-N7-Guanine in Rat Liver DNA: Impacts of Strain and Sex. Toxicol Sci 2011;121:57-62.

12. Lopez-Martinez LX, Parkin KL, Garcia HS. Phase II-Inducing, Polyphenols Content and Antioxidant Capacity of Corn (Zea mays L.) from Phenotypes of White, Blue, Red and Purple Colors Processed into Masa and Tortillas. Plant Foods Hum
Nutr 2011;66:41-7.

13. Huang B, Wang Z, Park JH, Ryu OH, Choi MK, Lee J, et al. Anti-Diabetic Effect of Purple Corn Extract on C57BL/KsJ db/ db Mice. Nutr Res Pract 2019;9:22-9.

14. Thiraphatthanavong P, Jintanaporn W, Supaporn M, Wipawee $\mathrm{T}$, Panakaporn W, Terdthai T, et al. Preventive Effect of Zea mays L. (Purple Waxy Corn) on Experimental Diabetic Cataract. BioMed Res Int 2018:1-8.

15. El-Bahr SM. Effect of Curcumin on Hepatic Antioxidant Enzymes Activities and Gene Expressions in Rats Intoxicated with Aflatoxin B1. Phytother Res 2015;29:134-40.

16. Long N, Suzuki S, Sato S, Naiki-Ito A, Sakatani K, Shirai T, et al. Purple Corn Color Inhibition of Prostate Carcinogenesis by Targeting Cell Growth Pathways. Cancer Sci 2013;104:298303.

17. Li J, Kang MK, Kim JK, Kim JL, Kang SW, Lim SS, et al. Purple Corn Anthocyanins Retard Diabetes-Associated Glomerulosclerosis in Mesangial Cells and db/db Mice. Eur J Nutr 2012;51:961-73.

18. Jing P, Bomser JA, Schwartz SJ, He J, Magnuson BA, Giusti MM. Structure-Function Relationships of Anthocyanins from Various Anthocyanin-Rich Extracts on the Inhibition of Colon Cancer Cell Growth. J Agric Food Chem 2008;56:9391-8.

19. Muangrat R, Williams PT, Saengcharoenrat P. Subcritical Solvent Extraction of Total Anthocyanins from Dried Purple Waxy Corn: Influence of Process Conditions. J Food Process Pres 2017;41:1-8.

20. Harakotr B, Suriharn B, Tangwongchai R, Scott MP, Lertrat K. Anthocyanin, Phenolics and Antioxidant Activity Changes in Purple Waxy Corn as Affected by Traditional Cooking. Food Chem 2014;164:510-7.

21. Singleton VL, Rossi JA. Colorimetry of Total Phenolics with Phosphomolybdic-Phosphotungstic Acid Reagents. Am J Enol Vitic 1981;16:144-58.

22. Chang CC, Yang MH, Wen HM, Chern JC. Estimation of Total Flavonoid Content in Propolis by Two Complementary Colometric Methods. J Food Drug Anal 2002;10:178-82.

23. Giusti MM, Wrolstad RE. Characterization and Measurement of Anthocyanins by UV-Visible Spectroscopy. Curr Protocol Food Anal Chem. 2005;2:19-31.

24. Lucas-Abellán C, Mercader-Ros MT, Zafrilla MP, Fortea MI, Gabaldón JA, Núñez-Delicado E. ORAC-Fluorescein Assay to Determine the Oxygen Radical Absorbance Capacity of Resveratrol Complexed in Cyclodextrins. J Agric Food Chem 2008;56:2254-9.

25. Huang D, Boxin OU, Prior RL. The Chemistry Behind Antioxidant Capacity Assays. J Agric Food Chem 2005;53:1841-56.

26. Blumenthal RD, Voigt W. Sulforhodamine B Assay and Chemosensitivity. Chemosensitivity 2005;110:39-48.

27. Wan XS, Zhou Z, Kennedy AR. Adaptation of the Dichlorofluorescein Assay for Detection of Radiation-Induced Oxidative Stress in Cultured Cells. Radiat Res 2006;160:62230 .

28. Nouroozi VR, Noroozi VM, Ahmadizadeh M. Determination of Protein Concentration Using Bradford Microplate Protein Quantification Assay. Int Electronic J Med 2015;4:11-7.

29. Tietze F. Enzymic Method for Quantitative Nanogram Amounts of Total Glutathione. Anal Biochem 1969;27;502-22.

30. Günzler WA, Kremers H, Floha L. An Improved Coupled Test Procedure for Glutathione Peroxidase (ec1.11, 1.9.) in Blood. Z Klin Chem Klin Biochem 1974;26:444-8. 
31. Mannervik B. Measurement of Glutathione Reductase Activity. Curr Protocols Toxicol 1999;1:7.2.1-4.

32. Kanagaraj K, Raavi V, Visweswaran S, Gnanasekaran ST, Dhanashekaran S, Peruma V. Technical Note on CytokinesisArrested Binucleated Cell and Micronucleus Assay. J Radiat Cancer Res 2017;8:180-5.

33. Vipin A, Raksha R, Kurrey NK, Anu A. Venkateswaran G. Protective Effects of Phenolics Rich Extract of Ginger Against Aflatoxin B1-Induced Oxidative Stress and Hepatotoxicity. Biomed Pharmacother 2017;91:415-24.

34. Guerra MC, Galvano F, Bonsi L, Speroni E, Costa S, Renzulli $\mathrm{C}$, et al. Cyanidin-3-O- $\beta$-Glucopyranoside, a Natural FreeRadical Scavenger Against Aflatoxin B1- and Ochratoxin a-Induced Cell Damage in a Human Hepatoma Cell Line (HepG2) and a Human Colonic Adenocarcinoma Cell Line (CaCo-2). Br J Nutr 2005;94:211-20.

35. Choi KC, Chung WT, Kwon JK, Jang YS, Yu JY, Park SM, et al. Chemoprevention of a Flavonoid Fraction from Rhus verniciflua Stokes on Aflatoxin B1-Induced Hepatic Damage in Mice. J Appl Toxicol 2011;31:150-6.

36. Fasinu P, Bouic JP, Rosenkranz B. Liver-Based in Vitro Technologies for Drug Biotransformation Studies - A Review. Curr Drug Metabol 2012;13:215-24.
37. Yang X, Lv Y, Huang K, Luo Y, Xu W. Zinc Inhibits Aflatoxin B1-Induced Cytotoxicity and Genotoxicity in Human Hepatocytes (HepG2 cells). Food Chem Toxicol 2016;92:1725.

38. Reddy L, Odhav B, Bhoola K. Aflatoxin B1-Induced Toxicity in HepG2 Cells Inhibited by Carotenoids: Morphology, Apoptosis and DNA Damage. J Biol Chem 2006;387:87-93.

39. Lee J, Hye E, Lee K, Sook H. Alleviation of Aflatoxin B1Induced Oxidative Stress in HepG2 Cells by Volatile Extract from Allii fistulosi bulbus. Life Sci 2005;77:2896-910.

40. Wattanathorn J, Kirisattayakul W, Suriharn B, Lertrat K. Functional Drink Containing the Extracts of Purple Corn Cob and Pandan Leaves, The Novel Cognitive Enhancer, Increases Spatial Memory and Hippocampal Neuron Density Through the Improvement of Extracellular Signal Regulated Protein Kinase Expression, Choli. Rejuvenat Res 2018;21:431-41.

41. Intuyod K. Priprem A, Limphirat W, Charoensuk L, Pinlaor P, Pairojkul C, et al. Anti-Inflammatory and Anti-Periductal Fibrosis Effects of an Anthocyanin Complex in Opisthorchis viverrini-Infected Hamsters. Food Chem Toxicol 2014;74:20615. 